\section{Enhancing Mother-Based Interventions for Preventing Children Obesity}

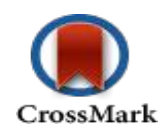

\author{
Xianglong Xu ${ }^{1,2,3^{*}}$, Yan Zhang ${ }^{1,2,3,4}$
}

${ }^{1}$ School of Public Health and Management, Chongqing Medical University, Chongqing, China ${ }^{2}$ Research Center for Medicine and Social Development, Chongqing Medical University, Chongqing, China ${ }^{3}$ The Innovation Center for Social Risk Governance in Health, Chongqing Medical University, Chongqing, China ${ }^{4}$ Department of Behavioral and Environmental Health, Jackson State University, Jackson, USA

*Corresponding author: Xianglong Xu, School of Public Health and Management, Chongqing Medical University, Chongqing, China, Tel: +8613594636537; Fax:+8602368485031; E-mail: xianglong1989@126.com

Received Date: November 26, 2015 Accepted Date: November 26, 2015 Published Date: November 29, 2015

Citation:Xu,X., etal. Enhancing Mother-Based Interventions forPreventing Children Obesity(2015)Int JFood NutrSci2(2): $153-154$.

\section{Introduction}

Childhood obesity is associated with increased prevalence of cardiovascular risk factors, increased the costs of healthcare, and premature death ${ }^{[1]}$. Obesity children is easier feel loneliness, sadness, and nervousness, and are more likely to have risk behaviours such as smoking and drinking ${ }^{[2]}$. Furthermore, childhood obesity is more likely to become obese in adulthood ${ }^{[3]}$.

Childhood obesity is a fast expanding disease around the world ${ }^{[4]}$ and is widely recognized as a major health problem ${ }^{[5]}$. In China, the prevalence of overweight and obesity among Chinese children has increased more than tripled, from 1.7\% (in 1982) to $5.3 \%$ (in 2002) among children aged 7-12 years old ${ }^{[6]}$. A national survey showed that the overweight and obesity prevalence was $19.2 \%$ among children and adolescents aged $7-18$ years, and the prevalence in rural areas $(22.6 \%)$ was higher than urban areas (16.2\%) in 2010 in China ${ }^{[7]}$. In 2011-2012, 8.4\% of 2- to 5-year-olds had obesity compared with 17.7\% of 6-to 11 -year-olds and $20.5 \%$ of 12 - to 19 -year-olds in the United States ${ }^{[8]}$. The prevalence of overweight and obese children has increased at an alarming rate in both developing and developed countries; the age of the onset of childhood obesity has also been gradually decreasing ${ }^{[9]}$.

Children obesity is caused by many factors, such as dietary factors, genetic factors, too little exercise, intrauterine growth environment and social environment factors. A survey of Lebanese children and adolescents showed that specific dietary, lifestyle, and socioeconomic factors could increase risk of obese ${ }^{[10]}$. Childhood obesity is related to the changes of environmental factors, such as living and school environments, diet, and physical activity patterns ${ }^{[11]}$. Studies found that factors early in the life course emerged may become the determinants of early overweight and obesity ${ }^{[12]}$.

Influenced by traditional ideas, many women, especially housewives in China, consider domestic service their responsibility, so they have more rights regarding domestic affairs, and some studies show that women pay greater attention to family diet and nutrition $^{[13]}$. Numerous studies show that mothers play a key role on children's dietary and exercise habits, particularly in the childhood orientation of dietary and exercise habits ${ }^{[14]}$. Women's ideas, attitudes, and behaviours regarding nutrition affect the growth and health of children ${ }^{[15]}$. Mothers, which are the direct caregivers of children, are the primary social force that influences children development. Maternal practices such as feeding style (dietary intake), instrumental behaviour (e.g., the use of food as a reward), role modelling (particularly weight-related behaviours), and nutritional knowledge have been shown to be associated with a child's eating and physical activity habits and weight status ${ }^{[16]}$. One study has explored the mother's position within the household power relationship, her autonomy in relation to other household members, and found that this influences her ability to provide for the health of her children ${ }^{[17]}$.

Previous study also that family-based intervention mode is effective in the treatment of overweight children between 8 and 12 years old ${ }^{[18]}$. Therefore, such an obesity intervention would help to reduce the rates of overweight and obesity in children, especially in some countries where women's ideas, mentality, and behaviours regarding diet are a dominant force in the family's diet and nutrition. It is necessary that further studies needs to be done in order to probe mother-based interventions for preventing 
children obesity, especially specific subgroup in the multi-ethnic country. This has important significance $n$ the prevention of children obesity.

\section{Reference}

1. Franks, P.W., Hanson, R.L., Knowler, W.C., et al. Childhood obesity, other cardiovascular risk factors, and premature death.(2010) N Engl J Med 362(6): 485-493.

2. Wang, F., Veugelers, P.J. Self-esteem and cognitive development in the era of the childhood obesity epidemic. (2008) Obes Rev 9(6): 615-623.

3. Whitaker, R.C., Wright, J.A., Pepe, M.S., et al. Predicting obesity in young adulthood from childhood and parental obesity. (1997) N Engl J Med 337(13): 869-873.

4. Daniels, S.R., Jacobson, M.S., McCrindle, B.W., et al. American heart association childhood obesity research summit. (2009) Circulation 119(15):e489-e517.

5. Pan, L., May, A.L., Wethington, H., et al. Incidence of Obesity Among Young US Children Living in Low-Income Families, 20082011. (2013) Pediatrics132(6):1006-1013.

6. Li, Y., Schouten, E.G., Hu, X., et al. Obesity prevalence and time trend among youngsters in China, 1982-2002. (2008) Asia Pac J ClinNutr 17(1): 131-137.

7. Sun, H., Ma, Y., Han, D., et al. Prevalence and trends in obesity among China's children and adolescents, 1985-2010. (2014) PLOS One 9(8): e105469.
8. Ogden, C.L., Carroll, M.D., Kit, B.K., et al.Prevalence of childhood and adult obesity in the United States, 2011-2012.(2014) JAMA311(8):806-814.

9. Wang, Y.,Lobstein, T. Worldwide trends in childhood overweight and obesity. (2006) Int J PediatrObes 1(1): 11-25.

10. Nasreddine, L., Naja, F., Akl, C., et al. Dietary, lifestyle and socio-economic correlates of overweight, obesity and central adiposity in Lebanese children and adolescents. (2014) Nutrients 6(3): 1038-1062.

11. Wang, Y., Lobstein, T. Worldwide trends in childhood overweight and obesity. (2006)Int J PediatrObes1(1):11-25.

12. Tounian, P. Programming towards childhood obesity. (2011) Ann NutrMetab(58Supp12):30-41.

13. Ning Li, E.G., Junqing, Wu. The analysis of residents' nutrition knowledge, attitude, behavior and influence factors. (2008) Chinese Journal of Public Health 4(24):482-485.

14. Dabelea, D., Crume, T. Maternal environment and the transgenerational cycle of obesity and diabetes. (2011) Diabetes 60(7): 1849-1855. 15. Saaka, M. Relationship between mothers' nutritional knowledge in childcare practices and the growth of children living in impoverished rural communities. (2014) J Health PopulNutr 32(2):237-248.

16. Skouteris, H., McCabe, M., Swinburn, B., et al. Parental influence and obesity prevention in pre-schoolers: a systematic review of interventions. (2011) Obes Rev 12(5): 315-328.

17. Doan, R.M., Bisharat L. Female autonomy and child nutritional status: the extended-family residential unit in Amman, Jordan. (1990) SocSci Med 31(7):783-789.

18. Jelalian, E., Foster, G.D., Sato, A.F., et al. Treatment adherence and facilitator characteristics in a community based pediatric weight control intervention. (2014) Int J BehavNutrPhys Act 11-17.
Online ISSN: 2377-0619

Journal Title: International Journal Food and Nutritional Science Journal Short Name: Int J Food Nutr Sci
Ommega Online Publishers

E-mail: editor.foodscience@ommegaonline.com Website: www.ommegaonline.org 